\title{
2 Comparing renewable support mixes
}

\author{
Elin Lerum Boasson and Merethe Dotterud Leiren
}

\section{Introduction}

Renewables support schemes may be designed and combined in various ways. In the 1990s most countries had only one renewables support scheme, and this scheme was relatively simple and easy to grasp. After 2010 most European countries adopted encompassing and complex support mixes (Kitzing et al. 2012). For several decades, scholars have discussed how to characterize the most dominant support schemes, usually focusing on single instruments and not policy mixes. Adding insights to this literature, we offer a conceptualization of support-scheme mixes.

Support-scheme mixes differ along many dimensions; thus far the scientific debate has focused on distinguishing between more or less market-based approaches. In contrast we develop a conceptualization of support-scheme mixes that distinguishes between technology-neutral and technology-specific instruments. We take two dimensions into account: the degree to which differing technologies are awarded varying support; and the degree of exposure to the electricity price. To capture the overall technology-specificity of a renewables support mix, we include both dimensions as regards both large- and small-scale support schemes.

Applying the new conceptualizations to support-scheme mixes in six countries, we find that whereas France, Germany, Poland and the UK had technologyspecific support-scheme mixes by the late 2010s, Norway and Sweden had more technology-neutral mixes. Explanations that rely primarily on economic and technological factors have dominated research on renewable energy and climate transitions. We review this literature and conclude that, although these approaches have many good qualities, they are poorly suited for explaining cross-country variation in renewable support mixes.

\section{Technology-specific and technology-neutral support-scheme mixes}

\section{Differing categorizations of renewable support measures}

There is a significant literature on single policy instruments, while policy mixes have gained less scientific attention. For instance, there is little scholarly agreement 
on how to characterize various types of policy mixes (see discussion in Howlett et al. 2015). Like many other policy areas, this is also true for the literature on renewables support measures.

From the early 1990s until about 2010, investment support, fixed feed-in tariffs and electricity certificate schemes were the dominant games in town. Investment support was often calculated on a project-by-project basis (Community Guidelines 2001): non-reimbursable payments in the construction phase of a project (Kitzing et al. 2012: 195). Governments tended to calculate investment support by applying an 'extra cost' approach, where the cost of each renewable electricity project was evaluated against the cost of a conventional electricity plant, and the support corresponded to the additional costs of building the former.

Later, many countries developed fixed investment-support levels, which could vary between different technologies (Community Guidelines 2001, 2014). The first feed-in tariffs guaranteed renewables projects a fixed electricity price for a fixed period, often 15 to 20 years. The system differentiated among the various technologies, resulting in different subsidy levels per unit of generation for different renewables technologies (Buckman 2011: 4105; Kitzing et al. 2012: 194). In addition, renewables electricity had priority dispatch to the grid, which ensured that the electricity from the renewables plant would be bought. This system created predictable gains for renewables producers, but governments could not know in advance how much new renewables electricity would result from the system.

In contrast, electricity certificate systems mandate that a certain quota of the electricity consumed is to come from renewables (Darmani et al. 2016: 373). For every megawatt hour (MWh) of production, certificates are allocated to electricity producers. These certificates can be traded on a market, where the price is set by supply and demand. The demand hinge on the target the governments has set for the system. The price for certificates comes on top of the electricity price. Significant uncertainty relating to electricity prices as well as certificate prices created high investment risks for producers. Further, certificate schemes tend to be technologyneutral, making a broad range of renewables eligible for the same level of subsidies (ibid.: 376). Such systems are referred to by various labels: for instance, in the USA and Australia, the term 'renewables electricity standards' or 'portfolio standards' is used, whereas in Norway and Sweden, and in EU documents, the terms 'green certificates' or electricity certificates are used more often (ibid.: 373 ).

Until recently, academic as well as political discussions about renewables support were marked by deep disagreement as to which of the two schemes should and could be called 'market-based' - or whether all economic support measures could qualify as market-based. Initially, the promoters of electricity certificate schemes labelled this approach 'market-based', whereas feed-in schemes were called 'command-and-control' schemes (Toke and Lauber 2007: 677). Eventually, scholars began to refer to certificate schemes as being market-based (Boasson and Wettestad 2013; Darmani et al. 2016: 373; Linnerud and Simonsen 2017: 560), but there was great variation in how feed-in schemes were labelled. In 2005, a report from the European Commission (the Commission) concluded: 'both instruments are equally market-based in that the regulatory body sets either the price 
or the quantity and leaves the determination of the other to the market' (Commission 2005: 54). Similar views emerged in scholarly debates, although here it was more common to underline the regulatory aspects of the measures in question. For instance, Reinhard Haas and colleagues argue that both feed-in schemes and certificate schemes

rely on a command \& control approach of a planned economy. In one case the price is set, in another case the quantity is set; . . . [y]et on the other hand all of these systems are market-based: the goods are produced in a competitive market . . . it is important to note that this market in all cases is created by some kind of artificial demand.

(Haas et al. 2011: 2188)

Discussions were ideologically charged, and no consensus emerged. Eventually, as actual application of both types of schemes grew more complex, it became increasingly common to apply several support schemes in conjunction. Whereas the first feed-in tariffs set the full price, more recent feed-in premiums come as guaranteed add-ons to the electricity market price, or the electricity price is one of several elements that in conjunction decides the full price for renewable electricity. Feed-in premiums may apply for a fixed period or for a pre-determined production volume (Kitzing et al. 2012: 194). While producers of certain technologies tend to be given the right to receive fixed feed-in tariffs, feed-in premiums are often awarded as a result of a tendering procedure whereby only the winners of the auction are granted support (Community Guidelines 2014). Since the second decade of the 2000 s, competitive tendering procedures have rapidly ascended towards dominance in Europe as well as worldwide (Fitch-Roy et al. 2019).

Auctioning systems can be organized in a technology-specific way - either with different auctions for different technologies, or with differing sets of technology criteria applied to the same auction (CEER 2018). Governments may also operate with specific reference prices (or 'strike prices') for different technologies, or they may develop differing support calculation equations for varying technologies. Auctioning combined with feed-in-premiums can be almost technology-neutral if all technologies compete on equal terms, but various technology-specific elements may be introduced. Similarly, many electricity certificate schemes have been almost technology-neutral, but a range of technology-specific elements may be introduced (Buckman 2011; Rabe 2007).

\section{Two dimensions of technology-specificity variation}

Countries may design and combine the various types of support schemes (such as feed-in and certificates) in many ways. The actual functioning will depend on a range of differing design elements, and how various support measures are combined. Two dimensions are particularly important as regards the technologyspecificity of a given measure: differences in support levels offered to varying technologies, and electricity price exposure. Based on these two dimensions, 
Table 2.1 Dimensions of technology-neutral and technology-specific support schemes

\begin{tabular}{lll}
\hline \multicolumn{1}{c}{ IDEAL TYPES } & Technology-neutral & Technology-specific \\
DIMENSIONS & & \\
\hline $\begin{array}{l}\text { Difference in support } \\
\text { levels across technologies }\end{array}$ & Low & High \\
Electricity price exposure & High & Low \\
\hline
\end{tabular}

Table 2.1 describes ideal versions of a technology-specific and a technologyneutral renewables support mix.

First, the support level may differ across technologies. This can be achieved in many ways, for instance by developing differing support schemes for various technologies, or by allowing certain technologies to be included in more than one support scheme. It has become increasingly common for European countries to supplement large-scale schemes with highly technology-specific support for various types of small-scale technologies, for instance through diversified feedin tariffs or investment support rules for certain technologies, like solar. However, small-scale renewables may also be promoted by rather technology-neutral measures, for instance by offering the same investment support to a broad range of small-scale technologies. Under certain conditions, the very existence of different support schemes for small and large projects is an element of technologyspecificity in itself.

Electricity certificate schemes and the auctioning model are competitionoriented solutions, but they rely on different types and degrees of competition. The extent of competition-orientation is, for example, dependent on whether renewables producers compete for funding in the market or for entrance to the market (Leiren 2015). In the ideal version of certificate schemes (Darmani et al. 2016: 373), all renewable technologies compete in the same market and have the same support level. But adjustments can be made in order to achieve a technology-specific support level - for instance, by issuing more certificates for some technologies than for others, or by creating sub-markets for specific technologies (Buckman 2011; Rabe 2007).

As to auctioning-based systems, the number of technologies included in each auction will influence whether differing technologies are given differing support levels: the more technologies that compete within the same round of auctioning, the more similar the support levels offered across technologies will be (CEER 2018). We may also see geographical differentiation within auctioning schemes: differences in remuneration based on where a renewable energy project is located. Such criteria help to promote certain technologies in areas where developing these technologies would not otherwise be profitable. For example, in Germany, powerplant location was adopted as a criterion in the renewable energy law, to ensure that wind turbines would be profitable also in less windy regions (Leiren and Reimer 2021, this book). 
The support that companies compete for within an auctioning scheme may be a fixed or premium feed-in. In feed-in systems, governments create technologyspecificity by operating with differing reference prices for differing technologies. In feed-in premium schemes, technology-specific support levels are created by employing differing methods and/or criteria to calculate support levels across technologies (CEER 2018).

The procedures applied for determining whether actors are eligible for support differ from one support scheme to another, and this may indirectly influence differences in support levels across technologies. Electricity certificates, fixed feed-in tariffs and investment support entitle the producers of certain renewable energy technologies to receive support, whereas auctioning schemes provide support only to companies who have won a competitive round for financial support. Details in the design of support schemes are important for whether the support levels across technologies differ. For instance, electricity certificates may be open to any producer of renewable electricity in principle, thus offering all renewable electricity producers similar levels of support, but this may not necessarily be the case in practice. For instance, under the Swedish/Norwegian scheme, the producers of new, renewable electricity (that is, added production under the scheme) are entitled to the same support per MWh delivered on the electricity grid - regardless of which technology is used, whether the plant is located in Norway or Sweden or whether the additional production comes from building a new plant or from updating and expanding an existing one. However, in practice small producers are excluded because of an entrance fee (Teknisk Ukeblad 2014).

Also, fixed feed-in tariffs tend to restrict who is eligible. For instance, Germany's fixed feed-in scheme, which has been the key support scheme there since the 1990s, was until 2004 closed to the participation of large corporations and utilities (Leiren and Reimer 2021, this book). After 2016, most fixed feed-in schemes have included only small-scale projects.

Through competition, auctioning largely ensures that the least costly projects are granted support, whereas projects that would be profitable also without support do not receive support. The outcome of the first German offshore wind tender round in 2017 has shown that this may result in no renewables support at all, as the two successful bidders received awards for three projects on the basis of a price of 0 Euro cents/kWh (Ashurst 2017; on renewable energy costs, see IRENA 2018).

Second, renewables technologies may to varying degrees be exposed to the regular electricity price. In general, technology-specificity decreases where all renewable energies are subject to the same market exposure. As the Nordic certificate schemes are add-ons to the electricity price, all renewables projects in these systems are exposed to similar fluctuations in the regular electricity market (Darmani et al. 2016). By contrast, traditional fixed feed-in provided renewables producers with a fixed price, so few renewables producers were exposed to the electricity price at all. The shift to feed-in premium entails greater exposure to the electricity price, but this can be achieved in several ways and to varying degrees. A feed-in premium can be granted as an add-on, but it may also be calculated on 
the basis of a more complex equation where the electricity market price is only one component (CEER 2018).

By taking into account both dimensions - the score on difference in support levels across technologies, and the score on differences in electricity price exposure we can determine the degree of technology-specificity of a given support-scheme mix. In a highly technology-neutral mix, all technologies are offered the same support, meaning that there tends to be small, if any, difference in support levels across small and large projects.

We do not a priori characterize specific renewables support instruments as either technology-specific or technology-neutral. Feed-in tariff schemes tend to be more technology-specific because support remuneration is calculated (in part or fully) on the basis of technology-specific criteria. However, when feed-in is granted via auctions, technology-specificity is reduced as a competitive element is introduced into the granting of financial support. The way the auctions are organized and their frequency influence the extent to which technology-specificity characterizes the setting of the level of remuneration. Electricity certificate schemes are usually technology-neutral, but various features can be added that lead to increased technology-specificity. This applies also to investment support: it may be technologyneutral if all technologies are offered the same support levels and are equally exposed to the general electricity price, but it becomes less technology-neutral when varying technologies receive different levels of support. Moreover, most countries combine various types of support schemes. The schemes for large-scale and small-scale projects and technologies must be seen in conjunction in order to get a full picture of the renewables-support mix.

\section{Categorizing technology-specific or technology-neutral support schemes}

Turning to the mix of renewables support policies in Germany, the UK, Poland, France, Sweden and Norway, in which categories do they belong? Drawing on the case studies presented in Part II of this book, Table 2.2 summarizes the support mixes in these six countries. ${ }^{1}$ All six have specific schemes for small- and for large-scale support, although differing terms are used to describe the two.

First, we note that the degree to which different technologies are offered different levels of support varies. Technology-specific auctioning is the most common. Even when projects based on different technologies are included in the same auctions, differing criteria tend to be applied, so projects based on different technologies seldom compete directly with each other. Our case-study countries vary as to the number of technology categories they have and which technologies are accorded the most favourable conditions. All six distinguish between small- and large-scale projects - which in itself produces some variance in support levels across technologies. We see that whereas Germany, the UK, Poland and France apply technology-specific criteria for large-scale as well as small-scale renewables (except Poland for small-scale), Norway and Sweden offer the same level of support to almost all renewables technologies within each of the two broad 
Table 2.2 Comparing renewables support schemes in the six case-study countries (2016 as reference year)

\begin{tabular}{llll}
\hline $\begin{array}{c}\text { Design features } \\
\text { Countries }\end{array}$ & $\begin{array}{l}\text { Project } \\
\text { scale }\end{array}$ & $\begin{array}{l}\text { Difference in support levels } \\
\text { across technologies }\end{array}$ & $\begin{array}{l}\text { Electricity price } \\
\text { exposure }\end{array}$ \\
\hline GERMANY & $\begin{array}{l}\text { Large } \\
\text { Small }\end{array}$ & High & High \\
UNITED KINGDOM & Large & High & No \\
& Small & High & Some \\
POLAND & Large & High & No \\
& Small & Low & No \\
FRANCE & Large & High & High \\
& Small & Low & Some \\
SWEDEN & Large & Low & High \\
& Small** & Low & High \\
NORWAY & Large & Low (until 2021)* & High \\
& Small** & Low & High \\
\hline
\end{tabular}

* No new Norwegian projects will be included in the electricity certificate scheme after 2021.

** Small projects may be granted large-scale support in addition to small-scale support.

categories (small- and large-scale). Whereas the main scheme for renewables in Norway and Sweden - the electricity certificate scheme - ensures (in theory) that electricity from all types of renewables will be granted the same level of support, the feed-in premium schemes in Germany, the UK, Poland and France have support levels that vary with the technology. France has separate auctions for different technologies, as does Germany - but from 2018 Germany has a pilot where both wind and solar participate in the same competitive rounds. The UK has had a few auctions that included many technologies but has still applied highly differing criteria for the various technologies.

Norway and Sweden have separate small-scale systems, but this is a very moderate differentiation compared to the many technology-specific categories in the other countries. These two Nordic countries also have technology-neutral investment support schemes for small-scale renewables investment (where small-scale solar and windpower investments are granted the same level of support as a range of energy-efficiency technologies). The support in Norway is marginal, covering only installations in residential buildings. Hence, the overall differentiation in support level is far more pronounced in Germany, the UK, Poland and France than in Sweden or Norway.

Second, the support schemes differ as to the extent to which renewables projects are exposed to regular electricity prices. Countries with feed-in premiums apply various techniques to assess support levels, making comparison difficult. In Germany, the feed-in support is a clear add-on to the electricity price, whereas 
France uses complex equations to calculate premium tariffs, with electricity prices one out of many criteria applied. The British Contracts for Difference provides a top-up payment between the market price and a pre-defined 'strike price'. Poland applies reference prices: bids must be below these prices in order to be granted support, but projects that are chosen will obtain the price proposed in the auction for the whole support period. Within the technology-specific group, Germany's renewables projects are more exposed to the electricity market, making the profitability of renewables unpredictable. Polish renewables are the least exposed to electricity prices, but, until 2018, auctions for new support were organized for relatively small volumes of electricity at a time.

In Norway and Sweden, electricity certificates and investment support are awarded on top of fluctuating electricity prices, making renewables projects far more exposed to electricity prices than in the four other countries. Norway is to withdraw from the common green certificate scheme with Sweden in 2021, although it will continue to offer support for projects that have already been included in the scheme. After 2021, possibilities for support in Norway will be limited to small-scale electricity production in residential buildings, and with no differentiation between technologies.

There are cross-country differences in the design of the support schemes, but Germany, the UK, Poland and France have all ended up with support-scheme mixes characterized by technology-specificity for both small- and large-scale renewable electricity projects. Hence, we group these countries together as having a technology-specific approach. In contrast, we place Sweden and Norway - with their rather similar technology-neutral support-scheme mixes - in the technologyneutral category.

In all six case-study countries, the domestic support mix has developed and changed through intricate and at times rather opaque political and social processes. Indeed, it has been argued that, due to the severity, complexity and scale of the climate crisis, energy and climate policy development processes may be even more complex than is the case in other areas (Peters et al. 2017).

\section{The shortcomings of basing renewables policy assessment on economic factors and technological change}

Students of renewable energy policy and energy transitions have applied a range of differing theory frameworks to explain renewable energy developments and politics. In particular, technological change and economic dependency on fossil fuels are used as explanatory factors. These are obviously important when policy-makers decide whether to adopt, change or revise a given renewables support mix. For instance, it seems clear that when renewables schemes fail to boost the deployment of renewables, this serves as an impetus to change (see e.g. Mitchell and Connor 2004). Also, the costs related to different schemes create incentives for change (e.g. Boomsma and Linnerud 2015). Although economictechnological conditions and changes play a key role for renewables deployment 
and support-mix developments, such perspectives cannot alone explain the support-mix patterns identified in this book.

Macro-level political economy approaches tend to depict policy-makers as responding to economic-technical change, understanding changes in policy as related to shifts to instruments more efficient under the new conditions (Dobbin 1994: 7). Building on this tradition, Johannes Urpelainen and Michaël Aklin (2018: 180) argue that renewables will be more controversial politically in countries with large capital investments in fossil-fuel infrastructure, and that reduced costs of renewables will lead to convergence in domestic renewables policies as well as investments.

If economic-technological differences in the energy systems had strong explanatory value, then we should be able to identify similarities in energy systems and fossil-fuel shares within each of the groups (Germany, the UK, Poland and France on the one hand; Sweden and Norway on the other) and clear differences between them. However, with the exception of Norway, all these countries started out with high fossil-fuel shares in their energy systems in the 1970s; and although all have gradually reduced their fossil-fuel dependence, the reduction factors differ significantly within the group of technology-specific countries (Global Carbon Project 2019). Germany, the UK, Poland and France developed similar support schemes, even though their energy systems are very different and have followed varying change patterns. Whereas Polish electricity production has remained dominated by fossil fuels, Germany and the UK have lowered fossil shares, and the fossil shares in France have become marginal (Commission 2018: 23). Further, French electricity production has historically been totally dominated by centralized nuclear energy production; Germany and the UK have significant nuclear shares, whereas Poland has no nuclear whatsoever.

Lastly, the growth rates for renewables vary considerably. In 2004, 9\% of German electricity consumption stemmed from renewables, but this had risen to $34 \%$ by 2017 (Eurostat 2019). The UK had only 3.5\% in 2004, but an impressive 28\% by 2017 . Poland had a meagre $2 \%$ in 2004 , rising to $13 \%$ in 2017 , while France had $14 \%$ in 2004 and $20 \%$ by 2017 .

There are also sizeable differences in shares of energy source among the two technology-neutral Nordic countries. Although Sweden reduced its fossil-fuel dependency radically, it never approached the extremely high renewables levels in Norway, where electricity production throughout the period was almost $100 \%$ renewables-based (Global Carbon Project 2019). In Sweden the share of renewable-source electricity increased from 51\% to 66\% from 2004 to 2017 (Energifakta 2019; Eurostat 2019); however, from the 1980s and onwards, Sweden has also had considerable nuclear production, whereas Norway has none (Commission 2018: 23).

Thus, we may safely state that investments in differing types of power plants and infrastructures cannot provide satisfactory explanations of policy variation. Might changes in the cost of renewable energy technology over time provide better explanations of the differences and similarities in renewables support mixes? 
Since 2000, the costs of many renewables technologies have decreased. This has happened in unforeseen and unpredictable ways, with a surprisingly steep reduction process starting around 2008 (IRENA 2013, 2018). The rapid changes in costs made it challenging to develop support-scheme mixes that provided stable investment incentives without overcompensating renewables investors. The financial crisis from 2008 and onwards made it even more important for governments to control expenditures, including renewables-support spending. After 2010, the cost of electricity from bioenergy, hydropower, geothermal and onshore and offshore wind had come within the range of fossil-fuel-fired power generation costs between 2010 and 2018. In 2018 the International Renewable Energy Agency (IRENA 2018: 9) concluded that 'by 2020-2022, all existing available renewable power generation options will compete head-to-head with incumbents'. These developments reduced the need for renewables support altogether - and yet, most countries in our study have adopted encompassing renewables-support mixes which are planned to continue until at least 2030. Along every step of the way, it has been hard to foresee how costs would develop, and many predictions have been proven wrong (see Vox 2015 for an overview of failed predictions). Moreover, there have been significant differences in cost developments across differing renewables technologies and countries (IRENA 2018).

If these dramatic cost reductions provided the key explanation to changes in renewables policy, we would expect all countries to respond in similar ways, which would also explain the similarities across cases. However, cost reductions play differing roles in the six cases presented in this book. Whereas achieving cost reductions in renewables was often an important impulse for changes in support schemes, the governments in the six case-study countries understood and responded to the rapid technological changes between 2005 and 2010 in differing ways. The UK and Poland responded by shifting away from technologyneutrality and towards a more technology-specific system, while France and Germany responded by making their systems less technology-specific. They all ended up with systems that were more similar, but for different reasons. Moreover, Norway responded by abolishing its large-scale support altogether, whereas Sweden continued with its technology-neutral certificate scheme. As a result, the two Nordics came to differ more after the cost reductions then they had before. In contrast, the financial support for renewables in the technology-specific countries became more similar, although there is still considerable variation across the schemes.

\section{Conclusions}

In this chapter, we have introduced a new way to characterize and measure differences across support-scheme mixes - technology-specific and technologyneutral mixes. We find that Germany, the UK, Poland and France have largely technology-specific mixes, whereas those in Sweden and Norway are far more technology-neutral. We have noted some interesting variations, but the differences between the two groups are far greater than the similarities. Dominant analytical 
approaches to explaining variance in renewables support have tended to focus on economic and technological factors. We find them poorly suited to explain differences in support-scheme mixes across countries. The material structure and functioning of the energy systems in our six case-study countries, and global changes in the costs of renewable electricity technologies, provide a set of fundamental conditions for investments in renewables. However, actual domestic renewablessupport mixes are not a direct result of such technical and economic realities. An analytical framework is needed that pays far more attention to political and social factors - a major rationale for this book.

The multi-field framework presented in Chapter 3 (Boasson 2021) enables us to take into account various kinds of actors' structural power, as well as the culturalinstitutional features that shape the preferences of these actors, and the many multi-dimensional relationships and interdependencies among the wide range of actors involved in policy processes.

\section{Note}

1 Only schemes that offer support to new projects are included. Most EU countries also provide support to older renewables projects, based on support schemes in operation when the projects were originally granted support. Since this book aims to explain the state of renewables support as of 2016, the older schemes are not listed in this table.

\section{References}

Ashurst (2017) Offshore Wind: An Update on the First Tender Round. Ashurst Report. Frankfurt am Main: Ashurst.

Boasson, E.L. (2021) 'A dynamic multi-field approach', pp. 32-57 in E.L. Boasson, M.D. Leiren \& J. Wettestad (eds) (this book), Comparing Renewables Policy: The Role of Political, Organizational and European Fields. London: Routledge.

Boasson, E.L. \& J. Wettestad (2013) EU Climate Policy: Industry, Policy Interaction and External Environment. Farnham: Ashgate.

Boomsma, T.K. \& K. Linnerud (2015) 'Market and policy risk under different renewable electricity support schemes', Energy 89: 435-448.

Buckman, G. (2011) 'The effectiveness of Renewable Portfolio Standard banding and carve-outs in supporting high-cost types of renewable electricity', Energy Policy 39: 4105-4114.

CEER (2018) Tendering Procedures for RES in Europe: State of Play and First Lessons Learnt. Council of European Energy Regulators. C17-SD-60-03. CEER: Brussels.

Commission (2005) The Support of Electricity from Renewable Energy Sources. Communication from the Commission COM 627. Brussels: European Commission.

Commission (2018) EU Energy in Figures. Luxembourg: Publications Office of the European Union.

Community Guidelines (2001) 'Community guidelines on state aid for environmental protection', Official Journal of the European Communities (2001/C 37/03).

Community Guidelines (2014) 'Community guidelines on state aid for environmental protection and energy 2014-2020', Official Journal of the European Union (2014/C 200/01). 
Darmani, A., A. Rickne, A. Hidalgo \& N. Arvidsson (2016) 'When outcomes are the reflection of the analysis criteria: A review of the tradable green certificate assessments', Renewable and Sustainable Energy Reviews 62: 372-381.

Dobbin, F. (1994) Forging Industrial Policy: The United States, Britain, and France in the Railway Age. Cambridge: Cambridge University Press.

Energifakta (2019) 'Kraftproduksjon', Retrieved from https://energifaktanorge.no/norskenergiforsyning/kraftforsyningen/, 16 June 2019.

Eurostat (2019) 'Share of electricity from renewable sources in gross electricity consumption, 2004-2017 (\%)', Retrieved from https://ec.europa.eu/eurostat/statistics-explained/ index.php?title=File:Share_of_electricity_from_renewable_sources_in_gross_electricity_consumption,_2004-2017_(\%25).png, 16 June 2019.

Fitch-Roy, O.W., D. Benson \& B. Woodman (2019) 'Policy instrument supply and demand: How the renewable electricity auction took over the world', Politics and Governance 7(1): 81-91.

Global Carbon Project (2019) 'Selected country figures', Retrieved from http://folk.uio.no/ roberan/GCB2019.shtml\#selectedcountries, 17 June 2019.

Haas, R., G. Resch, C. Panzer, S. Busch, M. Ragwitz \& A. Held (2011) 'Efficiency and effectiveness of promotion systems for electricity generation from renewable energy sources: Lessons from EU countries', Energy 36: 2186-2193.

Howlett, M., How, Y.P. \& R. Pablo (2015) 'The parameters of policy portfolios: Verticality and horizontality in design spaces and their consequences for policy mix formulation', Environment and Planning C: Government and Policy 33: 1233-1245.

IRENA(2013)Renewable Power Generation Costs in 2011.Abu Dhabi: International Renewable Energy Agency. Retrieved from www.irena.org/-/media/Files/IRENA/Agency/ Publication/2013/Renewable_Power_Generation_Costs_in_2012_summary.pdf?la=en \&hash=548B1D4A7BEAF616A19B26D8DF07011A8B8F49E7, 16 May 2019.

IRENA (2018) Renewable Power Generation Costs in 2017. Abu Dhabi: International Renewable Energy Agency. Retrieved from www.euractiv.com/wp-content/uploads/ sites/2/2018/01/IRENA_Renewable_Power_Generation_Costs_embargo_light.pdf, 15 June 2019.

Kitzing, L., C. Mitchell \& P.E. Morthorst (2012) 'Renewable energy policies in Europe: Converging or diverging?' Energy Policy 51: 191-201.

Leiren, M.D. (2015) 'Scope of Negative Integration: A Comparative Analysis of Post, Public Transport and Port Services', Journal of Common Market Studies 53(3): 609-626.

Leiren, M.D. \& I. Reimer (2021) 'Germany: From feed-in tariffs to greater competition', pp. 75-102 in E.L. Boasson, M.D. Leiren \& J. Wettestad (eds) (this book), Comparing Renewables Policy: The Role of Political, Organizational and European Fields. London: Routledge.

Linnerud, K. \& M. Simonsen (2017) 'Swedish-Norwegian tradable green certificates: Scheme design flaws and perceived investment barriers', Energy Policy 106: 560-578.

Mitchell, C. \& P.M. Connor (2004) 'Renewable energy policy in the UK 1990-2003', Energy Policy 32(17): 1935-1947.

Peters, B.G., A. Jordan \& J. Tosun (2017) 'Over-reaction and underreaction in climate policy: An institutional analysis', Journal of Environmental Policy \& Planning 19(6): 612-624.

Rabe, B. (2007) 'Race to the top: The expanding role of U.S. State Renewable Portfolio standards', Sustainable Development, Law \& Policy 10: 10-16.

Teknisk Ukeblad (2014) 'Ennå har ingen solkraftverk i Norge fått elsertifikater', Teknisk Ukeblad, December. Retrieved from www.tu.no/artikler/enna-har-ingen-solkraftverk-inorge-fatt-elsertifikater/225458, 10 June 2019. 
Toke, D. \& V. Lauber (2007) 'Anglo-Saxon and German approaches to neoliberalism and environmental policy: The case of financing renewable energy', Geoforum 38: 677-687. Urpelainen, J. \& M. Aklin (2018) Renewables: The Politics of a Global Energy Transition. Cambridge, MA: MIT Press.

Vox (2015) 'The international energy agency consistently underestimates wind and solar power. Why?' Retrieved from www.vox.com/2015/10/12/9510879/iea-underestimaterenewables, 10 May 2019. 